\title{
Renoprotective Effect of Xanthine Oxidase Inhibitor, Topiroxostat
}

\author{
Hisayuki Katsuyama $^{\text {a }}$, Hidekatsu Yanai ${ }^{\mathrm{a}, \mathrm{b}}$, Mariko Hakoshima ${ }^{\mathrm{a}}$
}

Uric acid is an end-product of purines such as adenosine triphosphate (ATP), RNA and DNA. Approximately $40 \%$ of uric acid is derived from foods and remaining $60 \%$ is endogenously produced. About $75 \%$ and $25 \%$ of uric acid are excreted from kidney and intestine, respectively. Therefore, hyperuricemia in chronic kidney diseases (CKD) was previously considered as the result of renal dysfunction and not as the target for treatment. Recent epidemiological studies are challenging such a significance of hyperuricemia in CKD. A serum creatinine level is a predictor of end-stage renal disease (ESRD), and serum uric acid was shown to be a significant positive correlate of developing high serum creatinine in a Japanese cohort study [1]. Hyperuricemia (serum uric acid $\geq 6.0 \mathrm{mg} / \mathrm{dL}$ ) was an independent predictor of ESRD in women [2], suggesting that strategies to control serum uric acid levels may reduce the population burden of ESRD. The meta-analysis which included 15 cohorts with a total of 99,205 individuals and 3,492 incident CKD cases demonstrated a positive association between serum uric acid levels and risk of CKD in middle-aged patients, independent of established metabolic risk factors [3]. Further, another Japanese cohort study showed that elevated serum uric acid levels within the normal range (men $>6.3 \mathrm{mg} /$ $\mathrm{dL}$, women $>5.1 \mathrm{mg} / \mathrm{dL}$ ) at the onset of overt nephropathy resulted in an increased risk for declining renal function in type 2 diabetes patients [4].

In a prospective, randomized, controlled trial (RCT) of 54 hyperuricemic patients with CKD, patients were randomly assigned to treatment with xanthine oxidase inhibitor, allopurinol, 100 to $300 \mathrm{mg} / \mathrm{day}$, or to continue the usual therapy for 12 months [5]. There was a trend toward a lower serum creatinine level in the treatment group compared with controls after 12 months of therapy, although it did not reach statistical significance $(\mathrm{P}=0.08)$. In another RCT, patients with estimated glomerular filtration rate $(\mathrm{eGFR})<60 \mathrm{~mL} / \mathrm{min} / 1.73 \mathrm{~m}^{2}$ were randomly assigned to treatment with allopurinol $100 \mathrm{mg} / \mathrm{day}$ $(\mathrm{n}=57)$ or to continue the usual therapy $(\mathrm{n}=56)[6]$. In the

Manuscript submitted June 24, 2019, accepted July 4, 2019

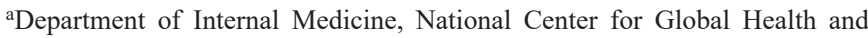
Medicine Kohnodai Hospital, Chiba, Japan

${ }^{\mathrm{b}}$ Corresponding Author: Hidekatsu Yanai, Department of Internal Medicine, National Center for Global Health and Medicine Kohnodai Hospital, 1-7-1 Kohnodai, Ichikawa, Chiba 272-8516, Japan.

Email: dyanai@hospk.ncgm.go.jp

doi: https://doi.org/10.14740/jocmr3913 control group, eGFR decreased by $3.3 \pm 1.2 \mathrm{~mL} / \mathrm{min} / 1.73 \mathrm{~m}^{2}$, and in the allopurinol group, eGFR increased by $1.3 \pm 1.3 \mathrm{~mL} /$ $\mathrm{min} / 1.73 \mathrm{~m}^{2}$ after 24 months. In the post hoc analysis of a longterm follow-up after completion of the 2-year trial, the treatment with allopurinol reduced the risk of renal events by $68 \%$ compared to the control group $(\mathrm{P}=0.004)$ [7].

We retrospectively picked up patients who had been continuously prescribed a new xanthine oxidase inhibitor, topiroxostat, for 3 months or more by a chart-based analysis, and compared serum uric acid, eGFR and urinary protein before the topiroxostat treatment with the data at 3 and 6 months after the topiroxostat treatment started. The study protocol was approved by the Ethics Committee of the National Center for Global Health and Medicine, and the study was performed in accordance with the Declaration of Helsinki.

Clinical and biochemical characteristics of patients studied at baseline were shown in Table 1. Changes in serum uric acid, eGFR and urinary protein after the start of topiroxostat treatment were shown in Table 2. Serum uric acid levels significantly decreased at 3 and 6 months after the start of topiroxostat as compared with baseline. eGFR did not change 3 months after, however, eGFR showed a trend to increase 6 months after. The number of patients who showed positivity for urinary protein significantly decreased at 3 and 6 months after the start of topiroxostat as compared with baseline.

Correlation between the decrease of serum uric acid levels and the increase of eGFR at 3 and 6 months after the start of topiroxostat were shown in Figure 1. At 3 months after, the increase of eGFR showed a trend to be correlated with the decrease of serum uric acid levels. At 6 months after, the increase of eGFR was significantly correlated with the decrease of serum uric acid levels.

Traditionally, uric acid crystals adhere to renal epithelial cells and induce an inflammatory response [8]. Uric acid stimulates proliferation of vascular smooth muscle cells in the afferent arterioles [9] and induced glomerular hypertension [10]. Elevated uric acid level is associated with induction of oxidative stress, endothelial dysfunction, elevation of renal vascular resistance, reduction of renal blood flow and renal arteriolopathy $[11,12]$.

In a recent systematic review and meta-analysis including a total of 12 RCTs with 832 CKD participants, pooled estimate for eGFR was in favor of lowering serum uric acid therapy with a mean difference of $3.88 \mathrm{~mL} / \mathrm{min} / 1.73 \mathrm{~m}^{2}(95 \%$ confidence interval (CI): $\left.1.26-6.49 \mathrm{~mL} / \mathrm{min} / 1.73 \mathrm{~m}^{2} ; \mathrm{P}=0.004\right)$, supporting our results [13].

In conclusion, topiroxostat improved urinary protein and 
Table 1. Clinical and Biochemical Characteristics of Patients Studied at Baseline $(N=41)$

\begin{tabular}{ll}
\hline Sex $($ male, $\mathrm{n}(\%))$ & $27(65.9 \%)$ \\
Age (years) & $64.4 \pm 11.8$ \\
Body height $(\mathrm{cm})$ & $162.5 \pm 8.1$ \\
Body weight $(\mathrm{kg})$ & $69.8 \pm 15.2$ \\
Body mass index $\left(\mathrm{kg} / \mathrm{m}^{2}\right)$ & $26.3 \pm 5.0$ \\
Systolic blood pressure $(\mathrm{mm} \mathrm{Hg})$ & $131.0 \pm 25.1$ \\
Diastolic blood pressure $(\mathrm{mm} \mathrm{Hg})$ & $72.6 \pm 19.3$ \\
Serum uric acid $(\mathrm{mg} / \mathrm{dL})$ & $8.4 \pm 1.5$ \\
HbA1c $(\%)$ & $6.2 \pm 0.8$ \\
Estimated glomerular filtration rate $\left(\mathrm{mL} / \mathrm{min} / 1.73 \mathrm{~m}^{2}\right)$ & $49.9 \pm 18.6$ \\
\hline
\end{tabular}

Table 2. Changes in Serum Uric Acid, eGFR and Urinary Protein After the Start of Topiroxostat Treatment

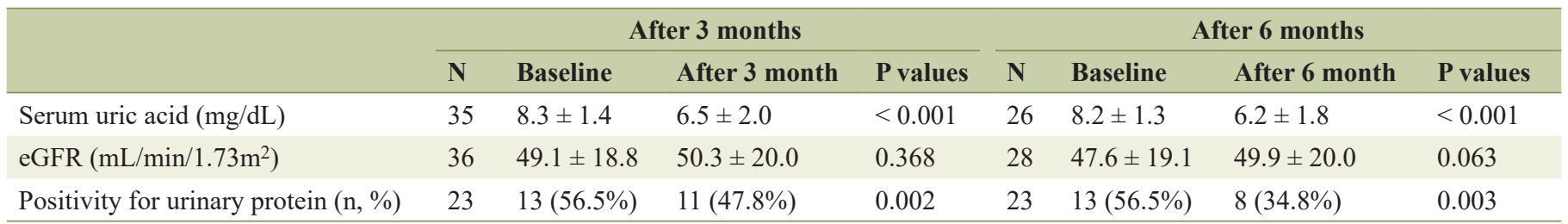

The paired $t$-test and Fisher's exact probability test were used to statistically analyze comparison in serum uric acid and eGFR, and comparison in positive rate of urinary protein, respectively.

eGFR, presenting renoprotective effect of uric acid lowering therapy.

\section{Acknowledgments}

We thank the staffs (Yukie Kawamura, Keiko Nakamura, Harue Aoki and Ayano Sakakibara) of the Division of Research Support, National Center for Global Health and Medicine Kohnodai Hospital.

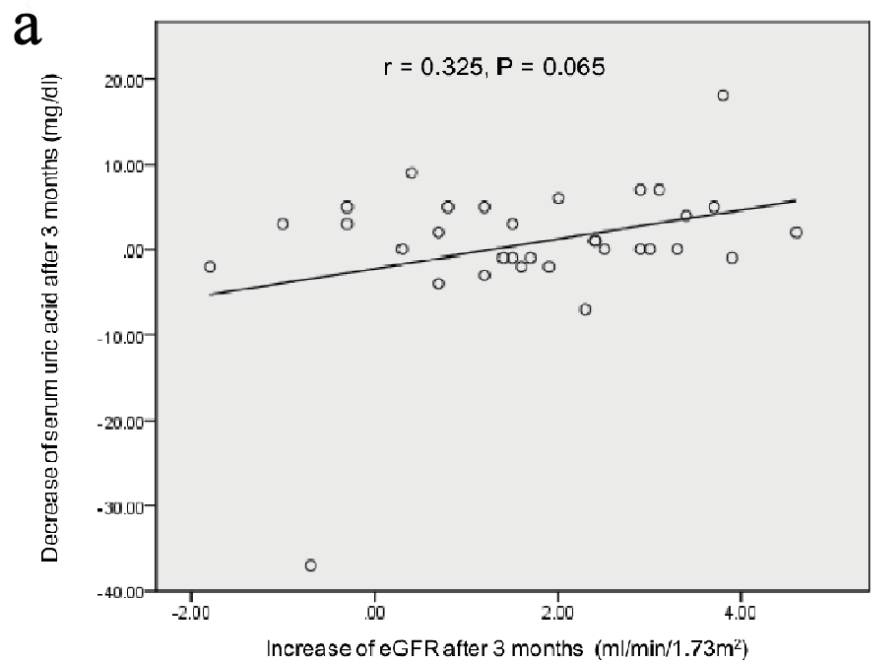

\section{Financial Disclosure}

Authors have no financial disclosures to report.

\section{Conflict of Interest}

The authors declare that they have no conflicts of interest concerning this article.

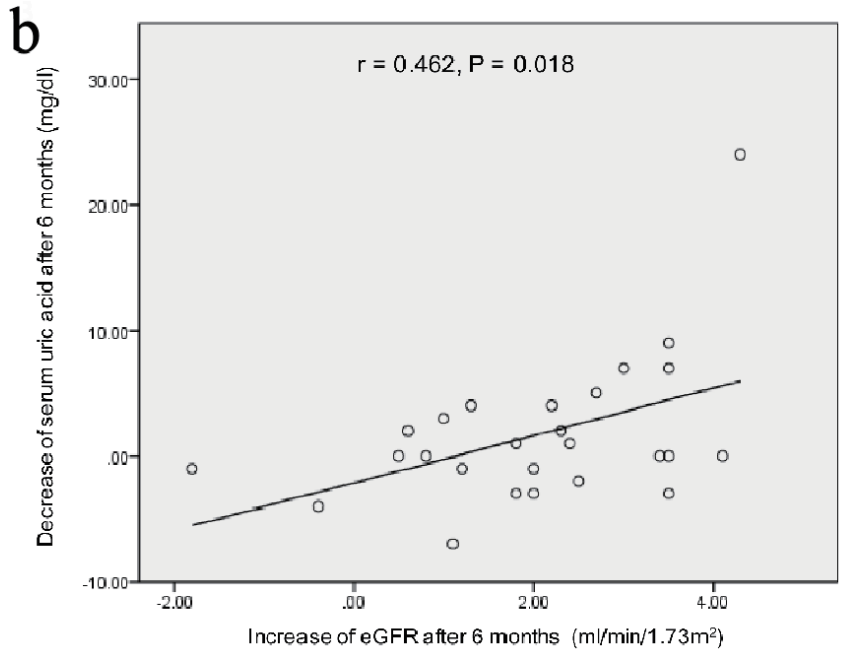

Figure 1. Correlation between the decrease of serum uric acid levels and the increase of eGFR at 3 (a) and 6 months (b) after the start of topiroxostat. r: Pearson's correlation coefficient. 


\section{Informed Consent}

Not applicable.

\section{Author Contributions}

H.K. and H.Y. designed the research. M.H. collected data. H.Y. analyzed data and wrote the paper. All authors read and approved the final paper.

\section{References}

1. Iseki K, Oshiro S, Tozawa M, Iseki C, Ikemiya Y, Takishita S. Significance of hyperuricemia on the early detection of renal failure in a cohort of screened subjects. Hypertens Res. 2001;24(6):691-697.

2. Iseki K, Ikemiya Y, Inoue T, Iseki C, Kinjo K, Takishita $\mathrm{S}$. Significance of hyperuricemia as a risk factor for developing ESRD in a screened cohort. Am J Kidney Dis. 2004;44(4):642-650.

3. Zhu P, Liu Y, Han L, Xu G, Ran JM. Serum uric acid is associated with incident chronic kidney disease in middleaged populations: a meta-analysis of 15 cohort studies. PLoS One. 2014;9(6):e100801.

4. Tanaka K, Hara S, Hattori M, Sakai K, Onishi Y, Yoshida Y, Kawazu S, et al. Role of elevated serum uric acid levels at the onset of overt nephropathy in the risk for renal function decline in patients with type 2 diabetes. J Diabetes Investig. 2015;6(1):98-104.

5. Siu YP, Leung KT, Tong MK, Kwan TH. Use of allopurinol in slowing the progression of renal disease through its ability to lower serum uric acid level. Am J Kidney Dis. 2006;47(1):51-59.

6. Goicoechea M, de Vinuesa SG, Verdalles U, Ruiz-Caro
C, Ampuero J, Rincon A, Arroyo D, et al. Effect of allopurinol in chronic kidney disease progression and cardiovascular risk. Clin J Am Soc Nephrol. 2010;5(8):13881393.

7. Goicoechea M, Garcia de Vinuesa S, Verdalles U, Verde E, Macias N, Santos A, Perez de Jose A, et al. Allopurinol and progression of CKD and cardiovascular events: longterm follow-up of a randomized clinical trial. Am J Kidney Dis. 2015;65(4):543-549.

8. Umekawa T, Chegini N, Khan SR. Increased expression of monocyte chemoattractant protein-1 (MCP-1) by renal epithelial cells in culture on exposure to calcium oxalate, phosphate and uric acid crystals. Nephrol Dial Transplant. 2003;18(4):664-669.

9. Mazzali M, Kanellis J, Han L, Feng L, Xia YY, Chen Q, Kang DH, et al. Hyperuricemia induces a primary renal arteriolopathy in rats by a blood pressure-independent mechanism. Am J Physiol Renal Physiol. 2002;282(6):F991-997.

10. Sanchez-Lozada LG, Tapia E, Avila-Casado C, Soto V, Franco M, Santamaria J, Nakagawa T, et al. Mild hyperuricemia induces glomerular hypertension in normal rats. Am J Physiol Renal Physiol. 2002;283(5):F1105-1110.

11. Sanchez-Lozada LG, Soto V, Tapia E, Avila-Casado C, Sautin YY, Nakagawa T, Franco M, et al. Role of oxidative stress in the renal abnormalities induced by experimental hyperuricemia. Am J Physiol Renal Physiol. 2008;295(4):F1134-1141.

12. Kohagura K, Kochi M, Miyagi T, Kinjyo T, Maehara Y, Nagahama K, Sakima A, et al. An association between uric acid levels and renal arteriolopathy in chronic kidney disease: a biopsy-based study. Hypertens Res. 2013;36(1):43-49.

13. Liu X, Zhai T, Ma R, Luo C, Wang H, Liu L. Effects of uric acid-lowering therapy on the progression of chronic kidney disease: a systematic review and meta-analysis. Ren Fail. 2018;40(1):289-297. 